\title{
THE POSITION OF MINANG-CHINESE RELATIONSHIP IN THE HISTORY OF INTER-ETHNIC GROUPS RELATIONS IN PADANG, WEST SUMATRA
}

\author{
Laila Kholid Alfirdaus ${ }^{1}$, Eric Hiariej ${ }^{1}$, Farsijana Adeney-Risakotta ${ }^{1}$ \\ ${ }^{1}$ Inter Religious Studies (IRS), Indonesian Consortium for Religious Studies (ICRS), Universitas Gadjah Mada \\ Email: alfirdaus_laila@yahoo.com
}

\begin{abstract}
Generally studies on pribumi and Chinese relationship in Indonesia are dominated with conflict perspectives. In fact, in practice, the relationship between the two groups can be very dynamic. Amongst social tension arose between them, there are often stories about social harmony, social engagement and social cohesion. This is also what we found in the Minang-Chinese relationship in Padang, West Sumatra. The Minang-Chinese relationship in Padang, West Sumatra, in current period has been not only about social tension. In spite of the strong tension arose due to differences in ethnicity and religious belief, they are strongly tied in running local trading, political party, and other areas of public policy making. Competition in economy often stands together with cooperation. This similarly works in local politics, and, recently, community recovery post 2009-earthquake. Such dynamic relationships is inseparable from ethnic politics constructed throughout Padang history in the past. This paper sees that the relationships of Minang and Chinese are inseparable from the ethnic politics constructed throughout Padang history. This paper tries to portray briefly the journey of Minang and Chinese relationship in Padang and the politics that contextualizes the making of that relationship based on literature research and in-depth interviews. Despite its shortness, this paper is supposed to provide background information for those interested in discussing the issue of ethnicity in Padang and West Sumatra.
\end{abstract}

Keywords: Minang, Chinese, History, and Politics

\section{INTRODUCTION}

Pribumi and Chinese relationship in the studies of ethnic politics in Indonesia is usually portrayed as full of conflict. In fact, the relationship between the two could be very dynamics. This can be found for example in the Minang and Chinese relationships in Padang, West Sumatra. Although the relationship between the two is sometime described as full of tensions (Olszewska, 2010), but they are quite often to get involved in collective works and social engagement. In scrutinizing this phenomenon, it becomes important to take into account the political context that tells us much about ethnic politics constructed throughout the history of the community. This article confirms that the relationship between the Minang and Chinese is inseparable from what they have been through throughout Padang history. Not only surrounded by tension, the Minang and Chinese have also experienced of cooperation, such as that during Revolution era in the 1950s. This seems to repeat in current the Minang and Chinese relationship, in which amidst the tension caused by religious difference and economic competition. The two 
ethnic groups have also been deeply engaged in post-2009 earthquake collective recovery. In this context, tracing the political context that is manifested through ethnic politics constructed during Padang's history becomes important.

As Derks and Roymans (2009, p. 1) argue, the construction of ethnic has close association with political system. This can also be found in the Minang and Chinese relationship in Padang. Throughout Padang history, we can see that the ups and downs in the Minang-Chinese relationship often linked to political structure in national and local level. This includes the periods of prior independence era (up to 1945), Revolution era (1945-1965/1966), New Order (1965/1966-1998), and Reformasi (1998). Throughout these periods we can see politics matter in the Minang-Chinese relationship construct.

However, it is not Minang if we do not find out adaptability and tactics to survive in the hardest times. Minang never become the passive recipient of their 'political' fate. As Hadler (2009) argues, Minang outweighs survival than anything else in their culture. This can be clearly seen, for instance, in reformasi era, where, unlike many other big cities in Indonesia, violence against Chinese did not happen in Padang. Although the Minang and Chinese relationship can be said to be not strongly engaged for ethnic and religious differences, as well as for economic competition (Olszewska, 2010), the absence of violence during reformasi is interesting to discuss.

This reminds us of Arifin's work of dualism in Minangkabau society, in which the Minang do not express directly their refusal or acceptance of Chinese. This contradiction is maintained in order to avoid conflict $(2012$, p. 29). If we refer to Sairin $(1995$, p. 91), this can also reflect the culture of democracy Minang maintained since ancient time, in which the Minang prefers diplomacy and dialogues, rather than conflict and violence in dealing with their matters. By tracing the Minang and Chinese relationship period to period, as this article tries to do, we will see how politics work in constructing interethnic relationship in Padang, West Sumatra. Nevertheless, we will also be reminded that Minang and Chinese are not passive recipient of their 'political' fate.
This article uses literature reviews and indepth interviews as methods for data collection. The literatures in this study include research report and manuscripts. In-depth interviews involve about 15 informants from both Minang and Chinese. Most informants are elderly who experience the first hand of the Padang history, and some of them are academics who have concerns on the Minang and Chinese relations.

\section{THE RISE OF ETHNIC FRAGMENTATION: FROM 15TH CENTURY TO 1945}

There is no consensus among social science scholars focusing on West Sumatra about the initial coming of Chinese to Padang, including the issues of who exactly initiated it, when it started, and how it happened. Some scholars mentioned that Chinese migration to West Sumatra, especially to Padang, is inseparable from the development of Padang to be a trading city, especially after VOC entered Padang, as well as the colonial government policy to expand their trading zones (Asnan, 2002, p. 728, Dobbin, 1983, Abdullah in Soebadio and Sarvaas, 1978, p. 205, Erniwati, 2011, p. 37 and 44). Colombijn (2004, p. 249 and 2006, p. 55) proposes the same argument that Chinese appeared to be in Padang since VOC opened its commerce centre in that city in 1664 after defeating Aceh that had ruled most Sumatran regions including West Sumatra in 15-16 Century. Indeed, Padang had been a migration destination and trading centre long before the coming of VOC, but the role of VOC in making Padang more attractive than in previous time is also very clear. The more economically active Padang since the coming of VOC had attracted migrants to come, including Arabians, Indians, Niasnese and Javanese.

Yet, some other scholars believed that Chinese had made a connection with Padang inhabitants long before the coming of VOC. The fall down of Malaka Kingdom to the hand of Portuguese government in 1511 had made the West Coast of Sumatra getting more hectic (Erniwati, 2011, p. 44, Hadi, 2004, p. 29). The change of ruler had made the change in Sumatran trading zone-which was mainly supported by sea transportation mode - to be more open to foreign traders. At that moment, 
West Sumatra that produced a lot of pepper was still under Aceh's ruler (Kathirithamby-Wells, 1969, pp. 453-479), and it was Pariaman, and not Padang, that became the center of West Sumatra, because Pariaman was noted to have big seaports. Padang, and other cities in West Sumatra, like Painan, as Colombijn (p. 57) argues, was the secondary important city after Pariaman in West Coast. Therefore, it is not a surprise when I found that most Chinese Padang I interviewed admitted that their origins are from Pariaman and, some are from, Painan. Considering such a geography politics, at first, Aceh ruler did not count the takeover of Padang by Minangkabau people in cooperation with VOC important. With the establishment of VOC commerce centre in Padang, Padang turned to be very attractive for outside traders (Brown, 2011, p. 47 and 67), including for Chinese. This is not to mention some political upheavals in Pariaman, which partially said to be caused by sentiment, as well as natural disasters, like 1926 earthquake, that later killed Pariaman's economy that highly relied on foreigners and seaports. The plural face of Padang identified with the existence of minority ethnic groups, including Chinese, Indians, Arabians, Bataknese, Javanese, Jambinese, and so forth.

During colonial era, the situation became very dynamic and challenging because the colonial government directly interfered the politics of ethnics through its ethnic policy. Social and political tension in Padang was begun when the takeover of Padang by the Minang and VOC from Aceh did not leave space for the Minang to participate in trading control. VOC dominated it and, of course, it encouraged the Minang struggle against VOC. Colombijn (2006, p. 56-58) said, instead of making the Minang as equal partner in trading, VOC put them as their employees. Yet, the Minang is not kind of lenient people (Dobbin, 1977). The harder VOC forced Minang to supply gold and peppers, the harder the resistance of Minang towards VOC. The Minang resistance had hit gold and pepper market in Europe, and thus meant a big loss for VOC. Padang gained a big pressure from village people surrounding the city. Yet, European and Chinese traders had been successfully defended it (p. 57). The loss of VOC, in addition to the loss of Dutch in France-
Dutch war in 1793-1795 had brought Dutch to be under France's ruler. The loss of France in war against Britain had brought East Indies, including Padang, under Britain's ruler. In 1814 Britain returned Padang to Dutch, and in 1819, Padang was no longer made as commerce centre for VOC, its status instead was changed to be the colonized area for the Dutch government. The West Sumatran export commodities were no longer gold and pepper, but coffee. In that matter, Chinese, together with British, and Dutchman operate local commerce houses that were connected with traders in India, Penang and Singapore (Colombijn, 2006, p. 61).

From the above discussion, we can see that although not holding the main control of Padang politics and economy, Chinese played crucial role in the running of Padang governance and trading. They remained gaining an important place in Padang local economy apart from the up and down of the colonial ruler's power due to European wars. Although being counted as the second class citizen, Chinese enjoyed the citizenship status given by the colonial government. They were also allowed to govern their community members with their own Chinese ruler - indeed under the control of the colonial government (Colombijn, 1995, p. 264).

The counting of Chinese as an important part in Padang's colonial governance is also strengthened with the colonial policy of population stratification (Soewarsono, 2000, p. 145-148) which implies the differentiation of population's rights and compulsions, i. e. in education, health, and economy accesses. The colonial government formally divided population as the following:

1) The first class citizen included Europeans.

2) The second class citizen included foreigners other than European like Arabians, Chinese, and Indians, called Timur Jauh.

3) The third class citizen included local ethnics (pribumi), consisting of native Minang and new comers, like Javanese, Jambinese, Bataknese, and Niasnese. As the manifestation of the policy of population stratification, the colonial government issued some policies that for most Indonesian scholars were considered as biased. In addition to privileging 
Europeans in education, health and economy, the colonial government also issued formal permission for Chinese to enter Padang freely in 1900 (Mackie and Coppel, 1976), as a basic token of that stratification policy. Indeed, the wave of Chinese migration to Padang had occurred prior 1900. Yet, economic expansion had encouraged the colonial government to push migration of foreigner, especially Chinese, in Padang. Chinese was also allowed to grouping with their fellow Chinese along the valleys of Gunung Padang and Batang Arau river, which means a closer access to transportation facilities, forming what current people call as "Kampung Cina", which is usually called Pondok. Living near the main river in Padang meant a lot for Chinese because it enclosed their access to the centers of economy and to transportation facilities.

There were also some public facilities in that Pondok including, for instance, temple (kelenteng) and traditional market, which could be counted as privileges for the second-class citizen like Chinese. Currently, building Church and houses for minority ethnic groups like Chinese and Batak are counted as hard issues in Padang, therefore the permission to build temple and traditional market in colonial era could be deemed as crucial facilities that Chinese could gain. Chinese temple and traditional market were situated side by side in the center of community in order to ease their access and mobility. When the temple was burnt in 1861 , the shops in the market, which were made up from bamboos, were then rented to other traders in order to cover the credit Chinese born to rebuild it. The market is called Pasar Tanah Kongsi. Because of that renting policy, Tanah Kongsi became plural. The traders not only included Chinese, but also Minangkabau, and the buyers included Chinese, Indische, high-class the Minang, and European women (Erniwati, 2011, p. 55). The mixture of ethnicities in sellers and buyers in Pasar Tanah Kongsi has made the market as one of the most plural and ethnically open market in Padang. The decision to rent bamboo shops and counters in Pasar Tanah Kongsi seemed to be the foundation for the current encounters of the Chinese and the Minang and of course other minority ethnic groups in Padang. Because of this small, yet crucial role of Pasar Tanah Kongsi in building Padang plurality,
Pasar Tanah Kongsi took crucial part in my analysis of Minang and Chinese solidarity in the later discussions.

In addition to privilege for establishing social group based on residential area, there is also privilege for establishing social organizations within internal Chinese. Among social organizations within Chinese, there is one that is the most important to mention, namely "kongsi". There are many Chinese organizations in Padang, including family organization (marga), dialect organizations, clan organization, and kampung organization. However, kongsi is the most crucial one because of its social function, as well as its strategic position in Padang local politics. The meaning of kongsi originally refers to trading communion, but in Padang it was developed to be cultural organization. In Padang kongsi refers to funeral communion, in which membership is determined by choice and only for men since the men age about 17 . There are two kongsi, namely Hok Teek Tong (HTT) with Indonesian name "Himpunan Tjinta Teman" and Heng Beng Tong (HBT) with Indonesian name "Himpunan Bersatu Teguh" formed in 19th century. The membership is fixed, so that changing it to another kongsi is prohibited. Membership contains rights and obligations, including for instance monthly fees, of which amount is ten thousand rupiah - as per May 2014; a period of my third fieldwork, a right of getting free of charge fee for men aging 60 or above, called as pension age, and social aids, like assistance for the sick members and aids for reconstruction post-2009 earthquake. Although the political role of kongsi had not yet been very clear, in current Padang politics, kongsi has been a bridge that connects Chinese with policy makers that are mostly the Minang. Some kongsi leaders are also local politicians. In later discussion, we can see how important kongsi is in the construction of the Minang and Chinese solidarity, including post 2009 earthquake recovery.

Other privileges Chinese, as the second-class citizen, gained were facilities to education access. Erniwati (2011, p. 56) calls it as equalization, meant to be an engineering of social structure to encourage Chinese to be by-education equal to Europeans. Access to education for Chinese, however, is inseparable with evangelization 
mission. Most schools provided for Chinese were those affiliated with the churches. Schools, therefore, did not only function as a place for education, but also for religious promotion. Colonialism and Chinese, as such, are inseparable from the explanation of Christianity development in Padang and West Sumatra, in general. Although political economy might be crucial in pushing the integration of Chinese with Europeans' religious belief, but this needs further study to elaborate.

The colonial government, however, did not only apply equalization policy. They also applied assimilation policy to Chinese, meant to connect Chinese with local residents. Indeed, this has nothing to do with the colonial intension for building social cohesion and integration. Rather, this was to help colonial government to have connection with local residents for the sake of colonial benefit. Erniwati (2011, p. 57) mentions that the colonial government relied on Chinese in terms of making contact with local residents. Trading connection and tax collection were among the areas the colonial government devoted to Chinese to deal with. It is clearly that the policy seems to be a double-edges sword in the sense that it appeared as if it accommodated Chinese to make connection with pribumi, but actually it was used to protect colonial interest.

The implication of such a double-edges policy can be looked, for instance, in the rebellion of Minangkabau towards the colonial government in 1908 , which is related to forced coffee plantation policy (Koffeecultuur) and coffee taxation system. The policy did not only encourage anti-Europeans among Minang, but also anti-Chinese. The involvement of Chinese in tax collection and other bureaucratic functions had worsened the Minang's impression and acceptance towards Chinese. Minang 1908 rebellion is mentioned to be the culmination of the Minang dissatisfaction towards the colonial government (Kahin, 2005, p. 11) not only for having undermined the Minang in the policy of koffeecultuur, but also for giving Chinese privilege to get involved within the implementation of the policy. Other issues included the placing of adat institution (Kerapatan Adat Nagari) as the lowest part of the colonial government structure, religious sentiment, in which Europeans and Chinese were known to be mostly non-Muslim, and discrimination, in which Chinese was given privileges than the Minang in terms of residency and economy. The discrimination and exploitative policy designs in social, economy and politics in the colonial era have inhibited the tension between communities that originated from different ethnic groups. Until independence in 1945, such a tension did not mean to erode. It was even strengthened, given the harder situation communities had to face for the political and economic instabilities in transition era.

\section{A "SWEET" RELATIONSHIP: REVOLUTION ERA (1945-1965/1966)}

During the first periods of post-1945 independence, Indonesia in general faced political instability, which was not only influential to the people's political life, but also to their social relations, such as in interethnic relationships in grass root level. Regionalisms, ideology friction among nationalist, religious and communist party (known to be "Nasakom", an abbreviation of "Nasional, "Agama", and "Komunis"), hard competition of power among the elites in national and local levels, and instability in economy are of factors that shaped the messy faces of Indonesian politics in that transition era. Such a hard situation also occurred in Padang, and was similarly influential to the relationship between different ethnic groups in daily life. The case of PRRI in 19502-1960s, which was followed with anticommunist movement in 1960s-1970s, is among the most crucial manifestations of those political complexities. Both PRRI and anti-communist movements later influenced much the political position of West Sumatra in Indonesian political landscape during New Order and Reformasi era, which was followed with complexities in interethnic relations in grass root level. Because of PRRI movement, the Minang gained the 'red stamp' labelling - meant to be a rebel - from the Indonesian government - which was dominated by Javanese. This stamp resulted in an exclusion of the Minang from politics and economy access in Indonesian bureaucracy. In daily life, tension between the Minang, Chinese and Javanese was unavoidable. The situation got worse when Padang entered anti-PKI era (Indonesian Communist Party or Partai Komunis Indonesia) in 1960s, worsened 
the relationship of the Minang and Chinese that was already distancing because of colonialism and PRRI movement. The following discussions present briefly PRRI and anti-PKI movements in Padang in Revolution era and their influences with interethnic relations in grass root level, which is useful to be the background information for current the Minang and Chinese relationship.

PRRI is an abbreviation for Pemerintah Revolusioner Republik Indonesia (Revolutionary Government of the Indonesian Republic). PRRI is a movement that was established to respond to the increasing role of PKI in national government (Ricklefs, 2001, p. 319), which at the same time coincided with the culminating problem of inequality in resource and power access in national and local decision making creating the so called Java and non-Java sentiment, and the growing corruption in government bodies (Syamdani, 2009, p. 39-47). PRRI proclaimed its establishment on 15 February 1958 in Padang. There were five demands proposed to Soekarno by PRRI supporters (Asnan, 2007, pp. 189-190), including the following points:

1) To reshuffle Indonesian ministries under Djuanda Cabinet within 5 x 24 hours;

2) To point out Hatta and Hamengku Buwono IX to form new ministries;

3) To let new ministries to work until the next general elections;

4) To suggest President Soekarno to act only based on Constitution (that asserted parliamentary system);

5) If the demands were not fulfilled, there will be an action taken to respond to it.

Ricklefs (2001, p. 318) and Setiyono (2008, pp. 788-789) argued that the movement gained crucial backup from the United Stated, which Soekarno and PKI worried most about. Among the prominent national figures in PRRI included Sjafrudin, M. Natsir, Burhanudin Harahap, Sumitro Djojohadikusumo, and Simbolon. The local figures included Ahmad Husein, a military commander of Region IV (West Sumatra), Dahlan Djambek, another military commander (Syamdani, 2009, p. 73) and Djamaloe'ddin Wak Ketok (Singgalang, 2000, in Syamdani, 2009, p. 104). The proclamation of PRRI had resulted in the firing of Ahmad Husein from his position as military officer (Colombijn 2006, p. 169, Wertheim, 1959, pp. 359-360). Another PRRI supporter figure, namely Sumitro, was noted to flee abroad. But, until today it remains unclear whether PRRI was truly a mutual collaboration between national and local politicians that were dissatisfied of Soekarno's leadership on the one hand, and of unequal welfare distribution on the other hand, or merely a making use of local resource by national politicians to support their political goal. A Minang leading figure I interviewed asserts that Minang was basically not interested in the movement. It was just Husein's action that did not represent Minang's political stance in general. He said,

Ahmad Husein is the chief of the struggle. The Prime Minister of PRRI was Sjafruddin Prawiranegara, and the ministers were national politicians. No one was from here (Padang, West Sumatra). The top position of PRRI was held by Ahmad Husein, which was not even becoming PRRI minister. ${ }^{1}$

Dealing with PRRI movement, there are at least two mainstreaming views that are important to discuss, namely separatism view and regionalism view. The separatism view perceives PRRI as a movement that aims to disintegrate from Indonesia. It has a close meaning with rebellion (pemberontakan). Regionalism is a movement that has regional orientation and coverage meant to be a protest or correction to the central government. The Indonesian government is among those that consider PRRI as a separatism movement (Syamdani, 2009, pp. 3-5). Scholars like Saafrudin Bahar and some other Minang leading figures are amongst those who consider PRRI as regionalism (Syamdani, 2009, p. 11).

Those who see PRRI as regionalism see PRRI movement as part of the critiques from the people in local region to the national government for particular problems and policies. The exploitation of West Sumatran resources, ${ }^{2}$ especially in coffee, pepper and coal mining, and the tendency of the national government to get closer to the left ideology (communism) represented by PKI that was rejected by most leading figures in Minang (Syamdani, 2009, p. 5, Ricklefs, 2001, p. 319) that were closer to Masyumi and PSI, are among the core issues frequently mentioned to have relations with the movement. ${ }^{3}$ Those people see PRRI just 
as a way to ask for more justice to the national government. He said,

What the Minang wanted was equal distribution in economy. (For the Minang) it seemed that the government focused too much on Java. Meanwhile, since contributing in Indonesian economy, the Minang wanted welfare, as well. ${ }^{4}$

Such a view was supported by scholars like Brown (2011, p. 188), who asserts that the movement was neither supposed to be separatism movement nor to delegitimize Soekarno. It aimed to seek for the supports for reform. In addition to regional sentiment, religion seems to also play crucial role in encouraging the movement. Natsir is among the leaders who believed that PRRI had relation to jihad for fighting against ideology that was contrary to Islam (communism). Kamardi Rais, a senior Minang journalist, in his biography mentioned about Natsir quoting Qur'anic verses and Hadist to encourage PRRI activists, which was listened respectfully and very carefully (Refrisul and Efrianto, 2013, p. 34)

Some supporters of regionalism view see that separatism (pemberontakan) attribution attached to PRRI was merely of PKI's propaganda that was unhappy with the existence of PSI (Partai Sosialis Indonesia - Indonesian Socialist Party) and Masyumi in the Indonesian government that was operated through the parliamentary system at the moment. It is widely known that PSI and Masyumi were among those that were actively against PKI in Indonesian political stage. With its separatism propaganda on PRRI, PKI meant to use military to attack its political rivals (PSI and Masyumi) (Syamdani, 2009), although later it is found that it was military that made use of PKI to regain its influence before Soekarno in order to regain its power in Indonesian political contestation (Anderson and McVey, 2009, p. 26). On the other hand, PKI saw that PRRI was merely its political rivals' manoeuvres that were supported by the United States to reduce Soekarno and PKI's role in Indonesian politics that was known to be very close to communism (Ricklefs, 2001, p. 319). Attack on pro-PRRI was supposed to show that Indonesia was not allied to the US. Later, the US withdrew its support to PRRI rebels to moderate
anti-US sentiment in Indonesian government.

Anderson and McVey's argument later seems to be proven, that it was military that made use of PKI instead of the other way around, which can be seen from the replacement of PKI-affiliated bureaucrats and leftist military officers in Padang with anti-PKI bureaucrats and military officer figures after PRRI defeated, and its activists were jailed until 1961 (Feith, 1962, pp. 525-531, Colombijn, 2006, p. 193). As such, leftist and PKI-affiliated officers enjoyed strategic position in government very shortly only during PRRI struggling era (1957-1959), when the Minang officers that supported PRRI choosing to leave their positions. After PRRI was defeated, anti-PKI wing in military office in Jakarta started to clean their organization from the existence of pro-PKI apparatus (Kahin, 2005, p. 369).

According to my interview with one of the traditional elites in the Minang, apart from the debate of whether PRRI is a separatism or regionalism movement, or who made use whom in the case, the apparent thing is that issue later had brought difficult position for the Minang in Jakarta's political contestation. He said,

There seemed to be misunderstanding with national army. They thought the Minang rebelled (wanted to separate from Indonesia). It is not rebellion. It is a protest to demand for justice. Unfortunately, the response of the national army, led by Yani, was too strict. Minang had to bear the consequence until Suharto ended his reign in $1998 .^{5}$

He gave an example, in which military officers and bureaucrats that were from the Minang in Jakarta were excluded for further promotion of their career. Even, for quite long time, military commander in West Sumatran Division was always filled with Javanese. Ricklefs identified that 60 to 80 percent of army officers were Javanese, whereas the ethnic group comprised only 45 percent of Indonesian population (2001, p. 320). Instead of intensifying their movement, this had forced local elites in Padang to be very careful, moreover with the Soeharto presidency after Revolution era (during New Order). Jakarta only chose those of the Minang officers who were successful to show 
their loyalty to the national government. Jakarta only wanted to make use these elites to handle potential subversive movement in West Sumatra (Kahin, 2005, p. 367). Yet, this meant high cost for West Sumatra, because later their interest was placed secondary than Jakarta's by those local elites. Of course, such an approach led to internal tension amongst the Minang in West Sumatra (Kahin, 2005, pp. 429-441).

In fact, PRRI is not only about the politics of elites. It had implication on politics at the grass root level, especially dealing with interethnic relations. In the context of Padang, amongst ethnic groups that were mostly influenced by PRRI are Minang, Javanese and Chinese. The identification of the national government and PKI with Javanese had encouraged the rise of sentiment against Javanese amongst Minang. The existence of Ahmad Yani, a military commander of Diponegoro Division in Semarang, Central Java, and other Indonesian army members, who were mostly Javanese, in Padang including, in an attack on 17 April 1958 (Colombijn, 2006, p. 169) had been a clear token for Javanese's role in Padang turmoil. Referring to Ricklefs (1981, p. 250-251), Amal (1986, p. 93-94) and Leirissa (1991, p. 212-217), Javanese army was known to be very mean and attack under Ahmad Yani's commander had killed thousands of people and forced the other thousands of them to leave West Sumatra to reside at the other islands through merantau (migration). It was just because General Nasution lobbied the government, then Ahmad Yani's army was withdrawn from Padang and being replaced with military commander from Siliwangi Division (West Java) that was known to be more 'humanist' than Diponegoro Division. He said,

There was no cultural approach (under yani's commander). After about 3,5 years of battle, Nasution came to Padang and instructed all the army and PRRI struggler to leave the battle field. ${ }^{6}$

Yet, Minang is not monolithic. The apparent complexities in Minang can be seen for instance through the division of adat and Moslem scholars. In the case of PRRI, for instance, there were some people who were active in the movement, but there were also some other who was not. Some of them even took part in pro-communism in PKI. Dealing with this, some people believe that Javanese took crucial role in spreading PKI's ideology in Padang through those that migrated to Padang since colonial era. ${ }^{7}$ Kahin (2005, p. 19) mentions those who had close relations with Javanese were usually from adat community. Adat and Javanese seemed to have intersecting interest in this case because adat had been long time neglected by Minang Muslim scholars since Padri war, in spite of the peace agreement between them that resulted in the Minang principles of "adat basandi syara', syara basandi kitabullah". Meanwhile, Javanese as new comers saw that adat and Muslim scholars' friction was an opportunity to gain support from adat community. Martens (2012, p. 17) and Kahin $(2005$, p. 394) assert that the Islamic people of West Sumatra that were affiliated to Masyumi had been in diametrical distance with Javanese that was suspected to promote communism in West Sumatra. The suspicion seems to be justifiable with the fact that PKI-Jawa had been equally influential to PKI-Padang Panjang, led by Tan Malaka, in organizing communist movement in West Sumatra (Kahin, 2005, pp. 17-20, Benda and McVey, 2009, p. 31).

However, unlike Javanese, or other people that supported Javanese (Colombijn, 2006, p. 185), Chinese did not experience attack or discrediting. Being aware that the Minang had been keeping the distance with Chinese during the colonial era, there seemed to be a change in the way Chinese responding to the issue. In PRRI movement, some Chinese preferred to be in the side of Minang (pro-PRRI). On the other hand, it is apparent that Minang had high resistance to Javanese and anybody that appeared to be pro-Java, which means to be pro-national government, which was dominated by leftist wing. There were, of course, some of the Chinese that preferred to be neutral. As a Chinese man I interviewed asserts, "Chinese preferred not to be in either side because it would lead them to further difficulties." 8 The most important thing of his involvement in PRRI for him was to save the kampung residents surrounded his environment. He confirms the involvement of some Chinese and Nias people in PRRI movement. In order to differentiate Chinese that got involved in PRRI or merely being a member of kampung 
security, the man explains the people used a ribbon as a sign. Once an army approached them meant to capture them, the man says, they could easily argue that they were not part of PRRI. Otherwise, they would be in danger.

The man's explanation about Chinese participation in PRRI movement enriches what Erniwati said about Chinese during Revolution Era, which she claims as very safe. As Erniwati (2011, p. 97) argues, there were many Chinese that were involved in PRRI that supported Andalas university students, which also supported PRRI, by providing bus to transport to the university during that hard times. Amongst them is Oei Ho Tjeng (Erniwati, 2011, p. 97, Yusra, 1997, p. 135). In fact, there were some Chinese that chose not to get involved in either side, clarifying Brown's argument of Chinese's ambivalence (2011, p. 110-114). In that context of time and space, Chinese's ambivalence relatively helped them to avoid attack either from military or from PRRI. The fact that some Chinese men were involved in PRRI movement helped Chinese to gain protection from PRRI during the increasing tension of politics (Erniwati, 2011, p. 97). Equally, the fact that military established its office in Pondok, and sometime was able to force Chinese to provide truck to transport military officers to outer regions, also had saved Chinese from military attack. After PRRI era ended, military moved Chinese that dwelled in sub-urban to the urban area, like Padang (Colombijn, 2006, p. 184). The politics and economic development, I guess, is one of the encouraging factors of the policy.

In addition to politics and economy issue, Chinese also had to face administrative stuff related to citizenship status. Although this did not have direct correlation with PRRI, this had been a crucial issue, which brought another problem to Chinese after PRRI movement was cleared up. The problem of citizenship administration arose because People Republic of China acclaimed that anybody born with Chinese descent was recognized as the citizen of the country. Meanwhile, the Indonesian government based on Citizenship Law Year 1958 asserted that anybody born in Indonesia were Indonesian citizen (Erniwati, 2011, p. 90, Suryadinata, 1994, p. 41 and Wibowo, 1999, pp. 107-110). The Indonesian government later offered three options for Chinese to decide their citizenship status, namely to be Dutch's citizen, People Republic of China's, or Indonesia's.

Later, the Indonesian government decided to claim Chinese that did not chose to be Dutch citizen as Indonesian citizen (Mackie, 1975, pp. 9-10). In fact, things did not run that easy. A Chinese informant I interviewed said, "Those who chose to be People Republic of China's citizen were deported to China by ships with the financial support from the Indonesian government." ${ }^{9}$ The man almost chose to return to China. However, his parent reminded him that there might be nobody that will recognize him because his relatives were not able to be identified anymore. He finally cancelled his intention to come back to China. On the other hand, there were still many Chinese people that were administered to (illegally) have dua-citizen. Based on Government Decree No. 1 Year 1950, the government finally firmly required Chinese to choose one only citizenship (Erniwati, 2011, p. 91, Badan Koordinasi Intelijen Negara, 1980, pp. 63-67). In Padang, it is claimed that 99.08 percent of Chinese were noted to choose Indonesian citizenship (Erniwati, 2011, p. 92, Sofwan, 1987 , p. 88). It seems that, in terms of administration, at least one problem was resolved. Yet, as the man has informed me, another bigger problem revived when PRRI issue was resolved and Indonesia entering a new phase of antiPKI movement in 1960 s to 1970 s. ${ }^{10}$ Next part discusses Minang and Chinese relationship in New Order context, which was begun with anti-PKI movement in the mid-1960s and continued up to 1998 reformasi.

\section{YEARS FULL OF OPPRESSION AND SOCIAL TENSION: NEW ORDER (1965/1966-1998)}

When PRRI era ended and Padang entered new era of anti-PKI movement, the relationship between the Minang and Chinese changed dramatically. Now, it is not only Javanese that gained communist labelling. The same experience also happened to Chinese. Exclusion and discrimination against Chinese dominated the figure of state's politics of ethnic, which inhibited the way people in the grass root built their relationship with Chinese. Therefore, it is not exaggerating if it is said that the end of PRRI never means the end of disaster. 
Padang movement to anti-PKI era in the mid1960s, which means the beginning of New Order, even means worse situation for the Minang and Chinese in Padang, firstly identified by the furthering distance between the two ethnic groups, and secondly the furthering access for the Minang to political resources in West Sumatra and Jakarta, as well as the more apparent discrimination against Chinese in Padang economy, politics and policy. This part discusses briefly anti-PKI movement in Padang, New Order, and the construction of the Minang and Chinese relationship in Padang in that era.

As argued earlier, although PRRI had been defeated, this never meant victory for PKI in Indonesian politics. Anti-PKI wing in military office kept their eyes to bar PKI manoeuvre in political stage. In Padang, preceding anti-PKI movement between 1961-1966, some political and military elites initiated the replacement of civil and military officers in Padang with antiPKI officers in order to balance PKI's influence in policy making. Up to 1966 , leftist politicians were recorded to dominate legislature body, government office, and military institution (Kahin, 2005 , p. 387). Untung, leader of 30 September 1965 event, and Abdul Latief were amongst leftist military officers that were ever posted in West Sumatra, and brought significant influence in West Sumatran military office. Meanwhile, Sapoetro was PNI leader that dominate legislature body who was known to be lenient to PKI and other leftist organization (Kahin, 2005, p. 387). In order to cease further domination of leftist politicians, Ahmad Yani strived to promote non-PKI officer to lead West Sumatra. Kahin (2005, p. 367) identifies that Ahmad Yani, based on Lieutenant General AJ Mokoginta's suggestion, pointed out Colonel Poniman, a Javanese military officer, as a chief of the military staffs in Padang. Later, Poniman was promoted to be chief commander in West Sumatran military region that also included areas of Riau and Jambi. This policy was strengthened with the appointment of West Sumatran governor in 1966, namely Harun Zain, a Jakarta born Minang intellectual and former rector of Andalas University, which was known to be non-leftist, to neutralize West Sumatran political climate. At first, there was a proposal to put a Javanese in governor position to squeeze Sapoetro who won election in parliament. However, Poniman insisted to put Minang in governor position in order to minimize the potential of ethnic fragmentation. At last, Harun Zain was mandated to be West Sumatran governor. Under Harun Zain's rule, slowly but sure West Sumatra rehabilitated itself before New Order's administration, as well as returned its access and resources by replacing non-Minang especially Javanese in government offices.

When 30 September 1965 event exploded in Java, Padang was actually in quite stable condition, in the sense that there was no violence against PKI, although resistance towards PKI was already high. Post-30 September 1965 event, the situation in Padang, and some other cities in West Sumatra, like Painan and Padang Panjang, was also quite conducive. People heard about the six military-general killing by PKI, which was led by Untung, but they chose to waiting for Soekarno's instruction to respond to the event (Kahin, 2005, pp. 384-396). Therefore, there was no particular reaction from people from any political affiliation. Jim Siegel's interview transcript, as Kahin (2005, p. 380) cited, revealed that people chose not to react, "because (we) do not have relationship with them (I assume the word "them" refers to PKI or politicians in Java or 30 September 1965 event)". ${ }^{11}$ A similar response can be seen in later political events like anti-Chinese violence in Reformasi era and Chinese traditional gate destruction in 20112012. ${ }^{12}$

However, about three weeks after 30 September 1965 event, KAMI (Kesatuan Aksi Mahasiswa Indonesia) and HMI (Himpunan Mahasiswa Indonesia), two leading student organizations in Padang, initiated a massive anticommunist movement. It is not clear who initiated the establishment of the organization, but rumor has it that the organizations have relationship with New Order. Such a movement was quickly followed with other youth organizations to conduct sweeping against PKI members and anybody that was suspected to have affiliation with PKI (Kahin, 2005, p. 380). PKI committees, legislature and governor assistant were reported to be captured by those organizations and were devoted to mass to get beaten until they died. In addition to PKI (registered) members, the next target of anti- 
PKI sweeping were farmers, labourers, ${ }^{13}$ and Chinese. ${ }^{14}$ My informant in Padang told me that, unfortunately, those included to be the target of anti-PKI cleansing were mostly innocent people. It was not rare that only because the people were given farming tools (cangkul), they then were listed to be anti-PKI sweeping target. ${ }^{15}$ Some others even were killed informally, which means that they were not identified in military list.

Yet, as Kahin (2005, p. 390) argues, anti-PKI movement in Padang, and West Sumatra in general, was not as terrible as in Java and Bali. Amongst areas in Sumatra that was noted to experience severe anti-PKI mass killing was North Sumatra, in which nearly 300.000 people that works in farming were killed (Kahin, 2005, pp. 282-294). Kahin's argument was strengthened with my Chinese informant's statement, in which anti PKI movement was not that terrible in Padang. He says that the most suffering experience he had to deal with is the takeover of Chinese assets, including schools and cultural buildings. Amongst Chinese assets being takeover, he mentions,

Included Hembing School, which is a language education school near Chinese temple (kelenteng), Tsing Hua School building in Parak Kalam, China consulate building in Jalan Cokro, and Eng Tsi School in 1967." 16

He adds,

"There was no severe mass killing like in Java, but the takeover of Chinese assets and the banning of Chinese symbols and identity, including in naming (was enough to make Chinese suffered)." 17

Nevertheless, this does not mean that that asset takeover and Chinese identity cleansing do not bring any impact to the Minang and Chinese relationship. An apparent result is, as an informant explains, because of the prohibition to expose Chinese identity, Chinese in Padang gets uprooted from their culture and language, which actually means a great lost not only for Chinese, but also for Indonesia, too. Currently, he estimates that only about 30 percent of Chinese in Padang that are able to speak basic Mandarin, not the advance one. In fact, it is found that mastering Mandarin is crucial in current Indonesian economic, political and social development. In daily social relations, anti-PKI movement that was manifested in antiChinese policy also means the start for further ethnic fragmentation in Padang.

Being asked about why the Minang acted so to Chinese, he says it might be because the Minang equated Chinese with PKI. Meanwhile, he argues that Chinese was actually only being bakiak, means to be PKI charity giver, instead of active members or supporters. Giving charity for him is different with being active members. Therefore, he refuses the allegation that Chinese as the same with PKI. For Chinese, he adds, their closeness to PKI activists was merely because of collegial (persahabatan), instead of ideological. He realizes that the equation of Chinese with PKI arose because the spreading of communism in Indonesia was inseparable from communism in China. Meanwhile, China as a state, and Chinese as ethnic group, for him, is totally different entity. Terrible treatment to Chinese at the time, for him, is also a representation of most Indonesians' view that Chinese was foreigner. This is irony, because, he asserts, as many other "ordinary" Indonesian citizen, Chinese also pays tax and even they pay higher than those "ordinary" citizen. Viewing Chinese as foreigner, for him, therefore, is against citizen equality principle. He, personally, disrespects such a policy by not paying the assigned amount of tax. ${ }^{18}$

When being traced further, the identification of Chinese with communism is also inseparable from the fact that in national level PKI became the only party that protected Chinese business and community (Ricklefs, 2001, p. 319) in the midst of hard political situation in the late 1950s and early 1960s. As Martens (2012, pp. 161-162) asserts, for the protection Chinese gained from PKI, Chinese had to pay particular fee to PKI that was used to fund the operation of PKI and Palace (Soekarno's administration). On the other hand, Chinese was given particular concession to supply raw materials for national needs, as well as to undergo import to supply machineries. The mutual relationship as such was well read by the Minang not only as an economic relation but more importantly as a political stance. This reminded the Minang of Chinese's view towards colonialism, in which colonialism was seen as a field of business for them 
instead of a practice of oppression the Minang suffered from.

In addition to such a historical experience during colonial era, the courage to get involved in anti-PKI movement among the Minang is inseparable from the considerable support from the state that initiated the movement as a response to 30 September 1965 event, later called G30S/PKI, to clean the state from the influence of communism. ${ }^{19}$ Locally, anti-PKI movement in Padang was also mentioned to have correlation with Islamic fundamentalism, which saw communism as an antithesis of Islam, embraced by most Minang. The establishment of Badan Kontak Perjuangan Ummat Islam (BKPUI) and the replacement of MTKAAM (Majlis Tinggi Kerapatan Adat Alam Minangkabau) that was known to have close attachment to Soekarno, with LKAAM (Lembaga Kerapatan Adat Alam Minangkabau) were amongst the steps to encourage social organizations that affiliated to Islam to support the anti-PKI movement in Padang (Kahin, 2005, p. 386). BKPUI and LKAAM with the support of Poniman were those that rejected Sapoetro, a leftist Javanese, to be West Sumatran governor (Kahin, 2005 , p. 387). Another step was by establishing KAMI and HMI in universities in Padang, as mentioned earlier, to operate anti-PKI movement. Amongst the steps KAMI and HMI took is to force the replacement of nagari officers that were suspected to be leftist and PKI supporters with thee anti-PKI ones (Kahin, 2005, p. 387). Some other youth organizations demanded for the delay of trading concession to Chinese and the kicking out of Chinese from West Sumatra. Soon, West Sumatra's export, which mainly consisted of coffee and pepper, decreased about 10 percent from 3,717 to 3,369 ton (Kahin, 2005, p. 392).

Although anti-PKI movement did not kill Chinese much, like the one happened in Java and Bali, this did not mean to bring insignificant impact for further Minang and Chinese relationship. Communist labeling in 1960s-1970s posed a new challenge to Chinese to be accepted by Minang in Padang, ${ }^{20}$ after they could resolve the procolonial label attached to them in colonial era (Erniwati, 2011, p. 74, Zed, 1998, pp. 124-125) by participating in PRRI (Erniwati, 2011, p. 97). Gerakan Kambuik (plundering) that was deemed to be a token for Minang's resistance to Chinese post-1945 independence (Erniwati, 2011, p. 74, Zed, 1998, pp. 124-125) was successfully ceased during the chaotic situation in PRRI era. PRRI even protected Chinese from plundering during the era of military intimidation (Colombijn, 2006, p. 183). When Padang moved to anti-PKI era and entered New Order, the situation turned worse and resulted in furthering distance between the Minang and Chinese. A Chinese informant says, regarding the Chinese identity cleansing and asset takeover,

There was no crucial protest from Chinese that could be posed. Somehow, Chinese was fear. They rather chose not to react to avoid further interethnic clash. ${ }^{21}$

Dealing with this, ironically, the Minang seemed not to realize that their support for antiPKI movement in Padang at the moment actually meant a support for the newly established ruler, namely Soeharto in an era called New Order, which later trapped the Minang to another difficult problem, namely political suspicion, exclusion and marginalization, due to past experience of the Minang in PRRI rebellion. Practically, the state's policy for cleansing PKI, which was conducted with the support of some the Minang residents, therefore, did not bring any benefit for Minang. In spite of amnesty given by Soekarno in 1961, during Soeharto's New Order, the state kept putting low trust to Minang that its leading figure were always put under the state's monitoring and the strategic positions in bureaucracy and military were granted to those who were loyal and could "serve" the national government. Kahin (2005, p. 403) asserts that the Minang elite was forced to support the state's party (Golkar) and deployed only figures that were loyal to the state. Daling with this, an informant says,

Living in New Order was very difficult for the Minang. It is unlike their past in prior and post-independence when there were many Minang intellectuals got involved in founding the state. Political career promotion in New Order was something rare. The Minang is like terjepit (getting pressed). ${ }^{22}$

Therefore, it can be said that both the Minang 
and Chinese equally faced difficult situation during the administration of Soeharto in New Order. Both ethnic groups also looked very careful to make a deal with Jakarta's elites. While Minang chose to adjust with what Soeharto wanted (Kahin, 2005, p. 400), like to win Golkar in West Sumatra (Kahin, 2005, p. 404), to adopt the idea of pemerintahan desa (village government) that the Minang looked like as Java in spite of the existence of nagari in Minang governance system (Kahin, 2005, p. 407), and to post local elites that were able to guarantee the clearness of West Sumatra from PRRI rebellion potential in West Sumatran bureaucracy and military strategic positions in provincial and district level like Azwar Anas (Kahin, 2005, pp. 409-412), Chinese chose not to get involved directly in politics, in order to survive. Citing Amal (1992, p. 193), Kahin (2005, 2005, p. 400) asserts that such a Minang strategy is close to the Minang pepatah petitih (proverb), namely takuik di ujuang badia, lari kapangka badia (Indonesian: takut di ujung bedil, lari ke pangkal bedil), which means that when people do not have any more power to rebel, adjusting with those that are more powerful is suggested in order to survive. That is why, in spite of the pressing situation Minang has to face during New Order, there were always Minang elites that were successful to take part in Soeharto's ministries. Azwar Anas, Abdul Latief, Emil Salim, and Hasan Basri Durin are amongst those elites that were quite influential in Soeharto's ruling government. Similarly, in spite of its limited role and access to politics, Chinese was also noted to be able to live side by side with Minang. In the early period of New Order administration, a Chinese man, namely Oei Ho Tjong that was known to ever be the supporter of Republic (Soekarno) in PRRI era by supplying weapons to the Indonesian Republic's military (which was pro-PKI ar the moment), was even noted to be chosen as LKAAM member (Colombijn, 2006, p. 184, Kahin, 1979, p. 225).

Yet, in daily life in grass root level, both ethnic groups remained in distancing relationship. In later New Order era, tension was even more apparent. Amongst the issues that always encouraged Minang and Chinese's tension were religion and economy. Based on a story told in interview, there was a case, in which a Chinese man was alleged to approach a Minang female student through unregistered marriage to persuade the girl to convert to Christianity. In the Minang, it was considered as blasphemy, which encouraged dispute between the Minang and Chinese in the mid-1980s. ${ }^{23}$ Another case, as a Chinese man told, "... is the unwritten policy of the city government to ban Chinese to operate their trading stalls in Pasar Raya." ${ }^{24}$ The government suggested Chinese to centre their economic activities in Pasar Tanah Kongsi, which was smaller in scale and further from the city centre than Pasar Raya. Instead of killing Chinese's economy, to my observation, the policy encouraged Chinese to open new trading spots through developing stores (ruko) surrounding Pasar Raya and Pondok.

Another Chinese man also told me that Chinese was not allowed to reside in village and sub-district. They may only reside in district area. Indeed, this hindered them to interact more widely with society. As a result, Chinese's residence was cantered in the city. As argued earlier, interestingly, although relationship building between the Minang and Chinese never run easy, direct clash or violent conflict was hard to explode. As Zainal Arifin says, typically the Minang was not interested to conflict, except the one that related to religion (Islam). In spite of the hard problems they have to face, they usually did not respond to the issues with physical violence. Arifin clarifies,

Minang basically did not reject Chinese, but it could not be said as well that the Minang welcome and accept them. As long as Chinese do not undermine the Minang's principle, Islam, the Minang may not take into account the existence of Chinese in Padang very seriously. ${ }^{25}$

This makes us clear that during New Order although both ethnic groups equally faced the political hardship, but both were also not engaged in their daily relationship.

\section{NEW SPACE (AND CHALLENGES) OPENED: REFORMASI ERA (1998 ONWARDS)}

Similar to the transition from Revolution era to New Order, things changed dramatically in the transition of New Order era to Reformasi. While in the transition of Revolution era to New Order 
Chinese experienced rejection after acceptance, in Reformasi era, Chinese gained a new space in public participation after a long period of oppression. However, it is widely known that Chinese have to pay very expensive for freedom they gain since Reformasi era. Chinese had been placed as scapegoat for the economic crisis that preceded reformasi. Official statements of Soeharto's ministries, like Adi Sasono and Rudini, contributed to the image making that Chinese was the cause, or at least the catalysts, of the crisis. The minority Chinese was alleged to dominate Indonesian economy causing a great disparity in Indonesian prosperity (Wibowo, 2001, p. 130). The statement that 3 percent Chinese dominated 70 percent Indonesian economy (Aditjondro, 1998, p. 8) strongly triggered public anger. Meanwhile, Soharto's family and crony's domination was never seriously mentioned (and properly tackled) in the case. Soeharto never confessed (let alone asked for apology) that the crisis arose because of his failure to manage Indonesian economy and rather used Chinese's domination in economy as an object to blame. In the midst of economic hardship, Wibowo (2001, p. 129), cited Subiyanto (2000, p. 3), mentions that there was a three-star general that stated, "There were "traitors" that tried to reduce the value of rupiah - an apparent reference to Sofyan Wanandi, a Chinese businessman, who refused to support the Cinta Rupiah campaign." With such a situation, some areas were successfully provoked to attack Chinese. Jakarta, Medan, Surabaya, Surakarta, Semarang and Makasar are amongst the cities where anti-Chinese violence was severe. Killing, plundering, burning, and even women mocking and gang-raping are amongst attacks Chinese experienced. At last, Soeharto was forced to resign from his presidency on May 1998 and this ended New Order's administration.

What is interesting about economic crisis that was related anti-Chinese violence in Padang? In spite of the fact Chinese was frightened and social tension was unavoidable, given the news about anti-Chinese violence from Jakarta, as well as rumors about attack to Chinese from Painan, Tiku and Silungkang, as a big city that was populated by a significant number of Chinese, violence against Chinese was not exploded in Padang. Students' protest was rather focused on
Soeharto's politics that was believed to have strong relations to local politics (Kahin, 2005, p. 424), instead of on ethnic politics and disparity issues. A Chinese informant admits that after the news of violence against Chinese in Jakarta and other big cities in Indonesia was heard in Padang, the situation in Padang was a bit frightening. He adds that most Chinese were worried about their safety. Yet, in his estimation, this only lasted for a month. He explains,

People started to think that economic crisis that was followed violence against Chinese was Jakarta's problem, and not theirs. Both Minang and Chinese agree that it was useless to get involved in the problem, the informant underlines. ${ }^{26}$

Accordingly, the frightening situation was replaced with cooperation between the Minang and Chinese in guarding Padang security. Another female Chinese informant says, she was so thankful to her fellow the Minang that protected her during reformasi, therefore she and her family felt saved. ${ }^{27}$ In addition to the political explanation, in which the Minang and Chinese did not feel that they were part of the problem, Erniwati says that economic factor also played crucial role in the minimized potential of ethnic violence. She explains, apart from the fact that Chinese was the strongest competitor for the Minang in trading, at the same time they were also their most important trading partner. Therefore, as Erniwati clarifies, the Minang believed that ruining Chinese's business will mean ruing Minang's economy, as well. ${ }^{28}$ The fact that Padang did not experience violence against Chinese in reformasi era seems to reflect their lesson learning from their experience in anti-PKI movement prior the rise of New Order, in which attack on Chinese's business had brought crucial impact on Padang local economy, which was noted to decrease about 30 percent. The Minang, on the other hand, looked more considerate and careful to have a deal with Chinese in early reformasi era.

Chinese involvement in politics also increased with the more opened opportunity for participation since reformasi era. And, though political party and practice politics, inclusive relationship between Minang and Chinese is also enabled. Golkar, PDIP, PAN, PKB and Demokrat are amongst parties that are popular amongst 
Chinese. Yohanes Lukman, Feryanto Gani and Albert Lukman are amongst Chinese prominent figures in Padang that have crucial roles in Padang politics. An important note about the political involvement of Chinese that is important to consider, as Erniwati (2011, pp. 175-193) identifies, is the role of kongsi (HTT and HBT). As Erniwati (2011, p. 176) argues, although kongsi never claims itself to be affiliated in particular political parties, its role in encouraging Chinese to get involved in politics is significant. This is unlike kongsi in New Order, in which kongsi chose to keep distance from direct political practice. In this case, the role of tuako (kongsi leader) is determining. However, this does not mean that tuako direct the political orientation of his members (directly). Although tuako's political choice might influence kongsi members' political choice, this does not mean that difference is not possible. In HTT, for instance, it is known that Feryanto Gani, HTT's tuako, was part of Demokrat Party's campaign team in 2004 election. At the same time, Albert Lukman, HTT's treasury, sits in PDIP's board member. In 20092014, Albert Lukman was even elected to be the member of West Sumatra Provincial legislature. In Erniwati's view (2011, p. 184), the enabled difference of political choice in HTT makes HTT looks more democratic than HBT. This also reflects a more effective and strong HTT leadership.

In spite of the good progress in terms of political recognition of Chinese since reformasi era, there is still challenge Chinese has to face internally and externally. Internally, Chinese has to face the increasing competition between kongsi. An NGO activist I interviewed confirms the competing tendency of the two kongsi to get "closer" to local politicians, which in his opinion might not bring further benefit for Chinese. In his view, there are still areas that need for response from policy making that still need for internal consolidation of Chinese, instead of their fragmentation, like poverty reduction, justice struggle and human right advocacy. ${ }^{29}$ Externally, Chinese still faces allegation that they collaborates with local politicians, merely to gain facilities to run their business. The issue of the close relationship between Fauzi Bahar, former mayor of Padang, with several Chinese elites, in social media discussion is often related to the consession
Chinese gains to build business center in Pondok, like hotel, restaurant, and the most controversial one is bar. This indicates that the acceptance and recognition of Chinese in Padang have not yet been full, and there is still great wall between Minang and Chinese to have a fair and open communication and inclusion. As such, although reformasi has brought new space for Chinese to get involved in policy making and gain political and social recognition in Padang, it brings other challenges for Minang in terms of internal consolidation and external inclusion.

\section{CONCLUSION}

From the aforementioned discussion shows the dynamics in the relationship of the ChineseMinang within the interethnic relations in Padang, is often inseparable from the political situation. In the colonial era, the colonial government policy that classified societies into three classes, influenced much the way the Minang saw their relationship with the Chinese. In that period, the Chinese was identified with colonialism, so that the Minang kept their distance with the Chinese.

When Indonesia gained its independence, the Minang turned its position to be the first class, and the Chinese as the second class. In fact, independence was not the answer for everything. The Minang was forced to face another hardship in terms of having relations with the national government, dealing with the economic and political inequality issues. The Minang's response to take part in PRRI as a protest to the national government, in fact, had brought Minang to a harder situation. At that moment, the Minang relationship with the Chinese turned into a harmonious relation. There were many Chinese people supported the Minang, for instance through giving them protection from the military intimidation.

The hardship, in fact, did not cease even until Suharto took over the power and governed Indonesia under his New Order regime. The Minang was excluded from accessing military and political career promotion during New Order. Exception was found only in those who were able to show their full support to Suharto. Yet, the sweet moment of relationship with Chinese in Revolution era did not continue in New Order era, for the identification of Chinese as PKI. The relationship 
of Minang and Chinese was getting more difficult with the massive discriminatory policy imposed by New Order government.

However, the Minang (and Chinese) are not the passive recipients of their 'political' fate. Both ethnic groups seem to learn much from their past. What we find out during the reformasi era in 1998 in which the Minang and the Chinese avoided direct clashes, in spite of the intense violence against Chinese in other big cities in Indonesia, shows us how both the ethnic groups made their experience in their past as a good lesson. The Minang had suffered a lot from breaking Chinese's economy in early New Order era, because empirically, the Minang had mutual dependence with the Chinese in trading. Similarly, the Chinese tried to be more aware of what happened to the Minang period to period, which is not always easy to handle. Disregarding the strong provocation, Minang and Chinese were successful to avoid violent conflicts during the early periods of political transition in 1998.

Tracing the Minang-Chinese's relationship in Padang history helps us understand the interethnic dynamics, as well as the politics behind the construction of that relationship. However, apart from the apparent role of the state and political elites in constructing interethnic relationship; society in grass root level is not always passive towards their fate. Society is also an active actor that takes part in interethnic relationship construct. Padang in reformasi era has given us a good lesson on this. And, this is also part of politics.

\section{REFERENCES}

Abdullah, Taufik. (1978). "Impact of colonial policy in Sumatra", in Haryati Soebadio and Carine A du Marchie Sarvaas. Dynamics of Indonesian History. Amsterdam: North-Holland. Chapter 10, 205-220.

Aditjondro, George Junus. (1998). "The Myth of Chinese Domination”. The Jakarta Post, 14 August, p. 4.

Amal, Ichlasul. (1992). Regional and central government in Indonesian politics: West Sumatra and South Sulawesi 1949-1979. Yogyakarta: Gadjah Mada University Press.

Anderson, Benedict RO'G and McVey, Ruth T. (2009). A preliminary Analysis of the October 1, 1965
Coup in Indonesia. Singapore: Equinox.

Arifin, Zainal. (2012). Bulu Babi: Politik Identitas Lakilaki Minangkabau. Jurnal Humaniora, Volume 4, No. 1, 29-36.

Asnan, Gusti. (2002). "Transportation on the west coast of Sumatra in the nineteenth century".

Bijdragen tot de Taal-, Land- en Volkenkunde, On the road The Social Impact of New Roads in Southeast Asia. Volume 158, No. 4,727-741.

Benda, Harry J and McVey, Ruth T. (2009). The Communist Uprising of 1926-1927 in Indonesia: Key Documents. Singapore:Equinox.

Brown, Colin. (2011). A Short History of Indonesia: The Unlikely Nation?. Singapore: Talisman.

Colombijn, Freek. (2006). Paco-paco (Kota) Padang: Sejarah sebuah Kota di Indonesia pada Abad ke-20 dan Penggunaan Tata Ruang. Yogyakarta: Ombak,

Colombijn, Freek. (2004). "Islamic influences on urban form in Sumatra in the seventeenth to nineteenth centuries". Indonesia and the Malay World. Volume 32, No. 93, 249-270.

Colombijn, Freek. (1995). "The colonial municipal council in Padang (Sumatra) as political arena". Journal of Southeast Asian Studies. Volume 26, No. 2, 263-288.

Derks, Ton and Roymans, Niko. (2009). Ethnic construct in antiquity: The role of power and tradition. Amsterdam: Amsterdam University Press.

Dobbin, Christine. (1983). Islamic Revivalism in a Changing Peasant Economy; Central Sumatra, 1784-1847. London: Curzon [Scandinavian Institute of Asian Studies Monograph Series 47].

Dobbin, Christine. (1977). "Economic Change in Minangkabau as a Factor in the Rise of the Padri Movement, 1784-1830". Indonesia. No. 23, 1-38.

Erniwati, E. (2011). Cina Padang dalam dinamika masyarakat Minangkabau: Dari revolusi sampai reformasi. PhD Dissertation. Jakarta: Department of History, University of Indonesia.

Feith, Herbert. (1962). The Decline of Constitutional Democracy in Indonesia. Ithaca: Cornell University Press.

Hadi, Amirul. (2004). Islam and State in Sumatra: a Study of Seventeenth-century Aceh. Leiden: Brill. 
Harian Singgalang. (2000). "Mengenal sosok pejuang PRRI Djamaloe'ddin Wak Ketok: Allahu Akbar, Bazooka pun Menggelegar”. 18 February.

Kahin, Audrey. (2005). Dari pemberontakan ke Integrasi: Sumatra Barat dan politik Indonesia 1926-1998. Jakarta:Yayasan Obor Indonesia.

Kahin, Audrey. (1979). Struggle for independence: West Sumatra in the Indonesian National Revolution: 1945-1950. PhD Dissertation. Ithaca: Cornell University.

Kathirithamby-Wells, J (1969). Achehnese control over West Sumatra pepper up to the Treaty of Painan of 1663. Journal of South East Asian History. Volume 10, No. 3, 453-479.

Leirissa, RZ (1991). PRRI Permesta: Strategi Membangun Indonesia tanpa Komunis. Jakarta: Grafiti.

Mackie, Jammie AC and Coppel, Charles A. (1976). “A preliminary survey”, in Jammie AC Mackie (ed.), The Chinese in Indonesia. Melbourne: Nelson.

Mackie, Jammie AC. (1975). The Chinese in Indonesia. Honolulu: The Australian Institute Press.

Olszewska, Dobrusia. (2010). "Chinese minority among Indonesian population: the case study from West Sumatra". Polish Ethnography. Volume 54, No. 1-2, 89-111.

Refisrul, R and Efrianto, E. (2013). Haji Kamardi Rais Datok Panjang Simulie: Biografi dan Hasil Karyanya. Padang: Balai Pelestraian Nilai Budaya (BPNB).

Ricklefs, MC. (1981). A History of Modern Indonesia; c. 1300 to the Present. London: Macmilan.

Ricklefs, MC. (2001). A History of Modern Indonesia since c. 1200.Third edition. London: Palgrave.

Sairin, Sjafri. (1995). "Demokrasi dalam Perspektif Kebudayaan Minangkabau". Jurnal Humaniora. Volume I, 87-93.

Setiyono, Benny G. (2008). Cina dalam pusaran politik: Mengungkap Fakta Sejarah Tersembunyi Orang Cina di Indonesia. Jakarta: Trans Media Pustaka.

Soewarsono, S. (2000). "Surabaya: Kota, penduduk, dan hubungan antar kelompok", in Thung Ju Lan (ed.), Etnisitas dan integrasi di Indonesia: sebuah bunga rampai. Jakarta:PMB-LIPI, 145-148.

Sofwan, Mardanas, at. al. (1987). Sejarah Kota Padang. Jakarta: Department of Education and Culture.
Subiyanto, Benny. (2000). The Politics of Chinese Indonesians after the fall of Soeharto's New Order. Mimeographed Personal Collection.

Suryadinata, Leo. (1994). Politik Tionghoa peranakan Jawa 1917-1942, translated by FS Hardoyo. Jakarta: Pustaka Sinar Harapan.

Wertheim, WF. (1959). Indonesian Society in Transition: A Study of Social Change. Second edition. Van Hoeve: The Hague and Bandung.

Wibowo, Ignatius. (1999). Retrospeksi dan Rekonstruksi Masalah Cina. Jakarta: Gramedia.

Wibowo, Ignatius. (2001). Exit, Voice and Loyalty: Indonesian Chinese after the fall of Soeharto. SOJOURN. Volume 16, No. 1, 125-146.

Yusra, Abrar (ed.). (1997). Tokoh yang Berhati Rakyat: Biografi Harun Zain. Jakarta: Yayasan Gebu Minang.

Zed, Mestika. (1998). Kota Padang pada masa Revolusi 1945-1950. Research Report, DHD 45 West Sumatra, Padang.

\section{(Endnotes)}

Interview on 17 May 2014 in Padang.

2 Interview with a Minang prominent figure on 20 May 2014 in Padang.

3 Interview with a Minang prominent figure on 20 May 2014 in Padang.

4 Interview with a Minang prominent figure on 20 May 2014 in Padang.

5 Interview with a Minang prominent figure on 20 May 2014 in Padang.

6 Interview with a Minang prominent figure on 20 May 2014 in Padang.

7 Interview with a Minang prominent figure on 20 May 2014 in Padang.

8 Interview with a Chinese prominent figure on 20 May 2014 in Padang.

9 Interview on 17 May 2014 in Padang.

10 Interview on 17 May 2014 in Padang.

11 Jim Siegel's interview with Nourmatias, ex-member of PKI, 8 August 1988.

12 It seems to be Minang typical not to interfere problems that are not their own.

13 Interview with Minang leading figure on 17 May 2014 in Padang.

14 Interview with a Chinese prominent figure on 20 May 2014 in Padang.

15 Based on interview with Minang leading figure on 17 May 2014 in Padang.

16 Interview with a Chinese prominent figure on 20 May 2014 in Padang. 
17 Interview with Interview with a Chinese prominent figure on 20 May 2014 in Padang.

18 Interview with a Chinese prominent figure on 20 May 2014 in Padang.

19 G30S/PKI refers to PKI movement where six military generals were killed by PKI leading activists given the long conflict of interest and power contestation in Indonesian politics since colonial era.

20 According to Interview with a Chinese prominent figure on 20 May 2014 in Padang.

21 Interview Interview with a Chinese prominent figure on 20 May 2014 in Padang.
22 Interview with Minang leading figure on 17 May 2014 in Padang.

23 Interview with aMinang informant on May 2014 in Padang.

24 Interview with a Chinese informant on May 2014 in Pasang.

25 Interview on 15 May 2014 in Padang.

26 Interview on 11 May 2014 in Padang

27 Interview on 23 November 2013 in Padang.

28 Interview on June 2010 in Padang.

29 Interview on June 2010 in Padang. 